\title{
Evaluation of lactation models in pasture-based dairy ewes in Bosnia and Herzegovina
}

\author{
Dragica Šalamon', Vinko Batinić2, Stanko Ivanković2 \\ Neven Antunac ${ }^{1}$, Alen Džidić ${ }^{*}$
}

\begin{abstract}
'University of Zagreb, Faculty of Agriculture, Svetošimunska cesta 25, 10000 Zagreb, Croatia
2University of Mostar, Faculty of Agriculture and Food Technology, Biskupa Čule, 88000 Mostar, Bosnia and Herzegovina

*Corresponding author: adzidic@agr.hr
\end{abstract}

\section{Abstract}

Milk of Kupres, Privor and Stolac dairy ewe breeds is used for the production of the fine cheese varieties. To the best of our knowledge there are no information about milk production and milk composition of these pasture-based dairy ewes. The aim was to determine the best lactation curve model in autochthonous pasture-based dairy ewes in Bosnia and Herzegovina. Milk production was recorded and milk composition sampled (milk fat and protein) during early, mid and late lactation in 129 Kupres, 141 Privor and 129 Stolac pramenka ewes. Four lactation models (Wilmink, Cubic, Ali-Shaeffer and Guo-Swalve) were compared and selected based on the lowest coefficient of determination and root mean square error. The Guo-Swalve model described all of the measured variables most successfully. Kupres pramenka dairy ewe was the highest producing breed with $139 \mathrm{~kg}$ of milk during 175 days of lactation $(0.79 \mathrm{~kg} / \mathrm{d}$; between lactation day 50 to 225) and showed the standard lactation curve. Privor pramenka produced $118 \mathrm{~kg}$ of milk during 175 days of lactation $(0.67 \mathrm{~kg} / \mathrm{d})$ and Stolac pramenka $101 \mathrm{~kg}$ of milk during 175 days of lactation $(0.58 \mathrm{~kg} / \mathrm{d})$. Both showed atypical constantly decreasing shape of the lactation curve common in low producing dairy ewes. The prediction of milk yield and milk composition from the Guo-Swalve model could be used by the national breeding program for the Kupres, Privor and Stolac pramenka sheep breeds. Additional research during a more stable management conditions is recommended for Privor and Stolac pramenka.

Key words: milk production, milk composition, lactation curve, autochthonous sheep breed 


\section{Introduction}

Kupres, Privor and Stolac ewe breeds are multipurpose pramenka sheep breeds which together with Vlasic (synonymous with Travnik or Dubska) pramenka sheep graze more than $50 \%$ of the total agricultural areas in the low-input highland systems of Bosnia and Herzegovina and are currently stable at about four hundred thousand sheep (personal communication with Agency for Animal Identification). The studied breeds are of pramenka type, which is the name descriptive for open fleece of ewe breeds with mixed wool. Pramenka sheep breeds are included in the Zackel/Valachian sheep group (Draganescu and Grosu, 2010). These autochthonous breeds are crucial for the preservation of sheep diversity as they harbour considerable genetic diversity, among which Privor breed shows the highest genetic distinctness (Salamon et al., 2014). Although in the neighbouring countries these breeds are used for meat production, in Bosnia and Herzegovina they are important in dairy production of the traditional handmade cheese varieties (Dozet et al., 1974). Therefore, the studied breeds show an additional income value as they are numerous in the current overall livestock production and predominant in the sheep production of the specific micro region.

Despite their potential, available research on milk production of Kupres, Privor and Stolac dairy ewe breeds in Bosnia and Herzegovina is only preliminary at this point and the breeds are not monitored using the official national standard testing methods. The first results on milk composition (Batinic et al., 2011), udder morphology (Batinic et al., 2018a) and lactation (Batinic et al., 2018b) confirm a great significance of the dairy aptitude of these breeds in Bosnia and Herzegovina. As the importance of ewe's milk market is increasing (Oravcova et al., 2015) research on ewe's milk yield, composition, lactation (Keskin and Dag, 2006; Cadavez et al., 2008; Karangeli et al., 2011), milking performance, suitability for milking (Dzidic et al., 2009; Salamon and Dzidic, 2014), udder conformation (Dzidic et al., 2004) as well as factors affecting them (Salamon et al., 2019) is ever so more available. Mathematical models describing the lactation are important in imputation of incomplete records used in genetic evaluation (Kaps and Spehar, 2004) as well as for time-dependent management decisions in different animal feeding strategies to satisfy the animal's requirement during various stages of lactation, reduce cost, and prolong the peak yield (Bilgin et al., 2010). In comparison to different systems or breeds lactation curve enables estimation of the peak yield, time of the peak, days in milk and the total milk yield. Lactation models that were designed to describe cow's milk production were tested for their suitability in ewes by Bilgin et al. (2010) and used for ewes (Karangeli et al., 2011) reared in extensive and semi-extensive conditions (Keskin and Dag, 2006; Cadavez et al., 2008). Complete lactation curves in ewes are rare (Pollott and Gootwine, 2000). Moreover, lactation curves estimation for sheep under extensive pasture-based system are very rare (Cadavez et al., 2008). The reason is the difficult measuring of the milk production within the first month or two of lactation when the ewes are kept with lambs.

The aim of this research was to determine the best lactation curve model in order to characterise the milk production and milk composition of autochthonous pasture-based dairy ewes in Bosnia and Herzegovina without official national standard testing methods.

\section{Materials and methods}

Kupres and Privor are high altitude breeds grazing from May until mid September, fed with hay in the period from November till April and $200 \mathrm{~g}$ of grain daily during the lambing period. Stolac breed feeds on dry pastures of warm submediterranean areas with mild winters and hot summers from May till mid October and is fed with $200 \mathrm{~g}$ of corn and barley mixture three weeks before lambing and one week after the lambing. All pasture-based dairy ewes lamb from January till March are kept with their lambs for at least 45 to 60 days of lactation when the lambs are slaughtered for very appreciated lamb meat supply. Ewes are handmilked twice a day after one month of suckling until the end of the lactation. For purposes of the current study, milk production was recorded for 399 ewes from three farms and milk composition samples (milk fat and protein percentage) were collected during early (d 
80-100), mid (d 140-160) and late (d 200-220) lactation by the researchers. The farms were chosen in order to correspond to the inherent origin of the breeds studied and to have the extensive and stable animal management. All ewes in the study were in their second to fifth parity. Milk fat and protein content were determined using the automated method and Milkoscan FT 120 (Foss Electric, Denmark) calibrated against known sample standards (IDF 1282: 2009).

In total, 790 records directy collected at the farm by members of our researcher team were used for 129 Kupres, 141 Privor and 129 Stolac pramenka dairy ewes. The distribution of records of each breed over days in milk was found similar between breeds and majority occurred in the middle of lactation: Kupres pramenka 106, 110 and 76; Privor pramenka 95, 104 and 55, Stolac pramenka 103, 100 and 41 records in early, mid and late lactation, respectively.

A geneal linear model for each trait (daily milk yield in kilograms, milk fat and milk protein percentage) was used. Four lactation models frequently used in extensive ewe and goat milk production research (Oravcova and Margetin, 2015; Cadavez, 2008) were compared using procedures GLM in SAS statistical software for each breed. Models were selected based on the lowest coefficient of determination and the root mean square error.

Wilmink (1987) model:

$$
Y i=a+b t+c e^{-0.05^{*} t}
$$

Cubic regression model:

$$
Y i=a+b t+c t^{2}+d t^{3}
$$

Ali-Schaeffer (1987) model:

$$
\begin{gathered}
Y i=a+b(t / 240)+c(t / 240)^{2}+d \log (240 / t)+ \\
\operatorname{elog}(240 / t)^{2}
\end{gathered}
$$

Guo-Swalve (1995) model (modified Khanderkar):

$$
Y i=a+b t+c t^{2}+d t^{3}+e \log (t)
$$

Where:

/ $\quad Y_{i}=$ measures of milk yield, milk fat and protein percentage,

I $a, b, c, d, e=$ parameters which characterize the shape of the lactation curve,

/ $t$ = days in milk,
Lactation persistency was calculated with the method according to Turner (1926).

\section{Results and discussion}

Kupres pramenka dairy ewe was the highest producing dairy ewe breed with $139 \mathrm{~kg}$ of milk during 175 days of lactation $(0.79 \mathrm{~kg} / \mathrm{d}$; between lactation day 50 to 225). Privor pramenka produced $118 \mathrm{~kg}$ of milk during 175 days of lactation (0.67 $\mathrm{kg} / \mathrm{d}$ ) and Stolac pramenka $101 \mathrm{~kg}$ of milk during 175 days of lactation $(0.58 \mathrm{~kg} / \mathrm{d})$. Lowest milk production of Stolac pramenka breed in comparison with Kupres and Privor Pramenka sheep breeds is understandable due to its smaller frame. The estimated model parameters and the goodness of fit of the lactation curve models for milk yield in the pasture-based dairy ewes of Bosnia and Herzegovina are shown in Table 1. The best overall goodness of fit (lowest RMSE and highest $\mathrm{R}^{2}$ ) was found in Guo-Swalve lactation model for milk yield of all of the three breeds. Values similar to $R^{2}$ in lactation models for milk yield of Kupres pramenka breed were observed in Churra da Terra Quente (Ca davez et al., 2008), Tushin (Bilgin et al., 2010) and Chios (Karangelli, et al., 2011) dairy sheep. The lactation curve for milk yield of Kupres pramenka was better estimated with increased number of parameters estimates in the model.

The Guo-Swalve lactation curve for milk yield is presented in Figure 1 for all of the three breeds. Kupres pramenka showed the usual pattern of the lactation curve (Pollott and Gootwine, 2000), while Privor and Stolac pramenka showed the atypical lactation curve without a clear peak phase in the early lactation which is common in low producing dairy ewes reared in harsh environmental conditions (Cappio-Borlino et al., 1997; Vázquez-Peláez et al., 2014). Ascending phase and the peak of the lactation curve are hard to estimate in extensive breeds. The reason is a long suckling period which can last for more than 60 days. High variation in daily milk yield during lactation is associated with pasture availability and other environmental effects (Carta et. al., 1995; Cappio-Borlino et al., 1997). Great influence of the feed and climate events that can affect the daily milk yield during a period of 60 days after the events' occurrence was shown by 
TABLE 1. Lactation model parameters for milk yield (kg) using Wilmink, Cubic, Ali-Schaeffer and Guo-Swalve models in Kupres, Privor and Stolac pramenka breeds

\begin{tabular}{|c|c|c|c|c|c|c|c|c|}
\hline \multirow[t]{2}{*}{ Breed } & \multirow[t]{2}{*}{ Model } & \multicolumn{5}{|c|}{ Parameters estimates } & \multirow[t]{2}{*}{$\mathrm{R}^{2}$} & \multirow{2}{*}{ RMSE } \\
\hline & & $a$ & b & c & d & e & & \\
\hline \multirow[t]{4}{*}{ Kupres } & Wilmink & 1.47 & -0.01 & 3.28 & & & 0.67 & 0.21 \\
\hline & Cubic & 2.04 & -0.01 & -0.000002 & 0.00000001 & & 0.71 & 0.20 \\
\hline & Ali-Schaeffer & -48.41 & 62.16 & -13.4 & 36.57 & -8.11 & 0.73 & 0.19 \\
\hline & Guo-Swalve & -25.51 & -0.27 & 0.001 & -0.000002 & 9.73 & 0.75 & 0.19 \\
\hline \multirow[t]{4}{*}{ Privor } & Wilmink & 0.97 & -0.002 & 2.36 & & & 0.22 & 0.21 \\
\hline & Cubic & 1.22 & -0.006 & 0.00001 & -0.00000002 & & 0.22 & 0.21 \\
\hline & Ali-Schaeffer & -15.62 & 20.23 & -4.17 & 12.49 & -2.93 & 0.22 & 0.21 \\
\hline & Guo-Swalve & -4.12 & -0.05 & 0.0002 & -0.0000002 & 1.76 & 0.22 & 0.20 \\
\hline \multirow[t]{4}{*}{ Stolac } & Wilmink & 0.87 & -0.002 & -0.85 & & & 0.21 & 0.14 \\
\hline & Cubic & 0.35 & 0.01 & -0.0001 & 0.0000003 & & 0.25 & 0.14 \\
\hline & Ali-Schaeffer & 12.05 & -17.30 & 5.86 & -6.96 & 1.18 & 0.25 & 0.14 \\
\hline & Guo-Swalve & -1.08 & -0.003 & -0.00005 & 0.0000002 & 0.52 & 0.25 & 0.14 \\
\hline
\end{tabular}

Pulina et al. (2005). Valverde et al. (2004) concluded that besides the genotype, differences in equations fitting are influenced by the sampling frequency. As evident in the milk yield lactation curve, milk yield decreases constantly from lambing to the end of the lactation causing the $b$ and $c$ parameter values to be out of the biological range. Therefore, it was difficult to calculate the peak yield and time of the peak yield (Pollott and Gootwine, 2000; Macciotta et al., 2005).

Lactation persistency was the only lactation indicator that could be determined based on the available model parameter estimates. It is interesting that the smallest and lowest producing Stolac pramenka breed using the submediterranean pastures shows the highest persistency of lactation 95 $\%$. Lactation persistency in Stolac pramenka breed

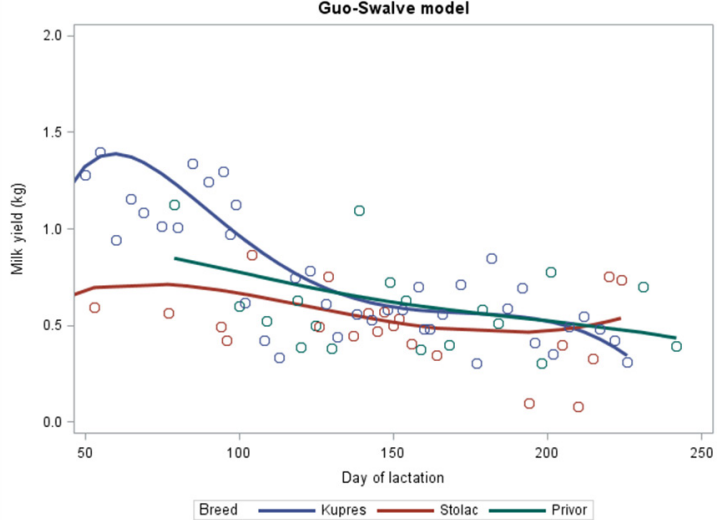

FIGURE 1. The Guo-Swalve model of lactation curve for daily milk yield in Kupres, Privor and Stolac pramenka breeds 
TABLE 2. Lactation model parameters for milk fat percentage using Wilmink, Cubic, Ali-Schaeffer and Guo-Swalve models in Kupres, Privor and Stolac pramenka breeds

\begin{tabular}{|c|c|c|c|c|c|c|c|c|}
\hline \multirow[t]{2}{*}{ Breed } & \multirow[t]{2}{*}{ Model } & \multicolumn{5}{|c|}{ Parameters estimates } & \multirow[t]{2}{*}{$\mathrm{R}^{2}$} & \multirow[t]{2}{*}{ RMSE } \\
\hline & & $\mathrm{a}$ & b & c & d & e & & \\
\hline \multirow[t]{4}{*}{ Kupres } & Wilmink & 3 & 0.03 & -21.98 & & & 0.55 & 1.70 \\
\hline & Cubic & 6.69 & -0.14 & 0.0018 & -0.000005 & & 0.70 & 1.40 \\
\hline & Ali-Schaeffer & 75.92 & 163.45 & -77.88 & -20.81 & -1.37 & 0.72 & 1.36 \\
\hline & Guo-Swalve & 146.9 & 1.2 & -0.004 & 0.0000044 & -49.5 & 0.72 & 1.36 \\
\hline \multirow[t]{4}{*}{ Privor } & Wilmink & -2.29 & 0.05 & 107.92 & & & 0.66 & 1.52 \\
\hline & Cubic & 10.64 & -0.16 & 0.001 & -0.000002 & & 0.66 & 1.52 \\
\hline & Ali-Schaeffer & 141.95 & -4.79 & 3.37 & -61.22 & 6.85 & 0.66 & 1.52 \\
\hline & Guo-Swalve & 53 & 0.16 & -0.00002 & -0.0000002 & -14 & 0.66 & 1.52 \\
\hline \multirow[t]{4}{*}{ Stolac } & Wilmink & 0.93 & 0.03 & 2.9 & & & 0.42 & 1.39 \\
\hline & Cubic & 4.16 & -0.06 & 0.0009 & -0.000002 & & 0.44 & 1.37 \\
\hline & Ali-Schaeffer & 16.72 & 70.71 & -29.58 & -1.08 & -1.51 & 0.44 & 1.37 \\
\hline & Guo- Swalve & 21.6 & 0.11 & 0.000098 & -0.000001 & -6.3 & 0.44 & 1.37 \\
\hline
\end{tabular}

was similar to that of Akkaraman ewes, reported by Keskin and Doug (2006). Privor and Kupres pramenka breed exhibited a bit lower lactation persistency: $86 \%$ and $72 \%$, respectively. It is obvious that lactation persistency in high producing and low producing animals differ. While in high producing dairy ewe lactation last the longest with high persistency (Elvira et al., 2013) in less producing under extensive dairy ewe herd management persistency is mainly determined by the nutrition level of the dairy ewe (Pollott, 2000).

Lactation curve modelling the milk fat percentage showed the trend similar to the one found in Istrian pramenka dairy ewe breed (Komprej et al., 2012). The lowest milk fat percentage ranged from 3 to $5 \%$ at the beginning of the lactation and the highest values were between 8 and $10 \%$ at the

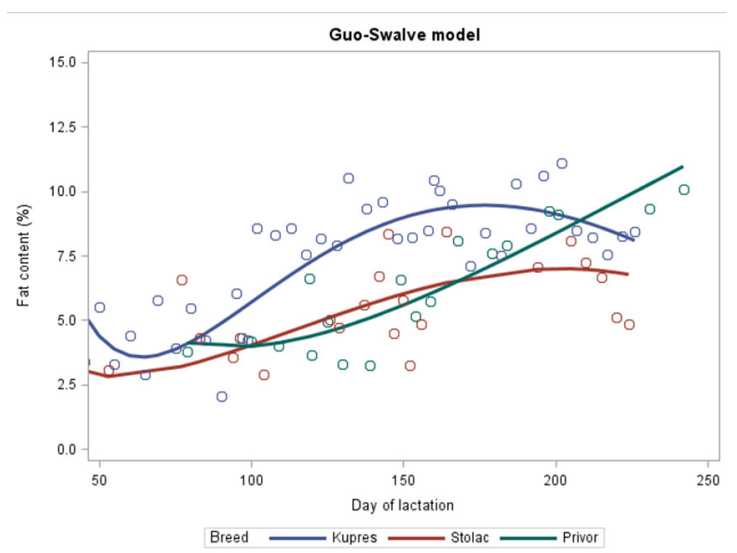

FIGURE 2. The Guo-Swalve model of the lactation curves for the milk fat percentage in Kupres, Privor and Stolac pramenka breeds 
TABLE 3. Lactation model parameters for milk protein percentage using Wilmink, Cubic, Ali-Schaeffer and Guo-Swalve models in Kupres, Privor and Stolac pramenka breeds

\begin{tabular}{|c|c|c|c|c|c|c|c|c|}
\hline \multirow[t]{2}{*}{ Breed } & \multirow[t]{2}{*}{ Model } & \multicolumn{5}{|c|}{ Parameter estimates } & \multirow[t]{2}{*}{$\mathrm{R}^{2}$} & \multirow[t]{2}{*}{ RMSE } \\
\hline & & $\mathrm{a}$ & b & c & d & e & & \\
\hline \multirow[t]{4}{*}{ Kupres } & Wilmink & 3.96 & 0.02 & 10.17 & & & 0.65 & 0.56 \\
\hline & Cubic & 7.04 & -0.05 & 0.0005 & -0.000001 & & 0.65 & 0.56 \\
\hline & Ali-Schaeffer & 4.05 & 35.31 & -10.69 & 4.80 & -1.57 & 0.65 & 0.56 \\
\hline & Guo- Swalve & 18.35 & 0.06 & 0.000006 & -0.0000002 & -3.99 & 0.65 & 0.56 \\
\hline \multirow[t]{4}{*}{ Privor } & Wilmink & 2.54 & 0.02 & 57.81 & & & 0.58 & 0.75 \\
\hline & Cubic & 6.19 & -0.009 & -0.00003 & -0.0000005 & & 0.65 & 0.69 \\
\hline & Ali-Schaeffer & -257.85 & 118.55 & -13.5 & 139.04 & -19.99 & 0.65 & 0.69 \\
\hline & Guo- Swalve & -70.84 & -0.58 & 0.002 & -0.0000026 & 25.46 & 0.65 & 0.69 \\
\hline \multirow[t]{4}{*}{ Stolac } & Wilmink & 3.51 & 0.02 & 11.96 & & & 0.40 & 0.75 \\
\hline & Cubic & 6.38 & -0.03 & 0.0002 & -0.0000002 & & 0.43 & 0.74 \\
\hline & Ali-Schaeffer & -29.21 & 25.52 & -0.49 & 20.29 & -3.27 & 0.43 & 0.74 \\
\hline & Guo- Swalve & -18.43 & -0.28 & 0.001 & -0.000002 & 8.95 & 0.43 & 0.74 \\
\hline
\end{tabular}

end of lactation. Possible reason for this trend are the variation in pasture quality and quantity, as well as in other temporary environmental factors that affect milk composition more than the milk yield (Carta et al., 1995).

Milk fat percentage expectedly increased throughout the lactation with higher variations at the beginning and at the end of the lactation curve (Figure 2). Kupres pramenka breed with the highest milk production showed the highest fat percentage troughout the lactation. The milk fat percentage models using more parameter estimates preformed better, as was the case with estimating the milk yield lactation curve in Kupres. Privor and Stolac pramenka showed better fit for the milk fat percentage than for the milk yield.

Modelling the milk protein percentage showed the fit very similar to the fit of the milk fat percentage models (Table 3 ). Protein pecentage among all of the three breeds analysed was very similar and ranged from around $5 \%$ in the early to $8 \%$ in the late lactation (Figure 3). Similar values were found in Improved-Valachian, Tsigai (Oravcova et al., 2015) and Churra (Gonzalo et al., 1994; El-Saied,
1998) ewe breeds with somewhat higher values at the end of their lactations.

As expected, milk fat and protein percentages showed the patterns opposite to the milk yield lactation curve pattern (Cappio-Borlino et al., 1997) with the milk fat and protein percentages increasing with time after lambing.

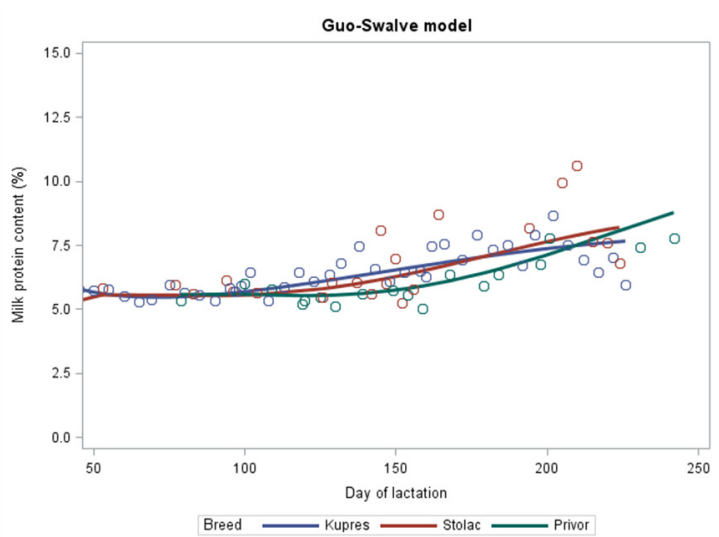

FIGURE 3. The Guo-Swalve model of the lactation curves for the milk protein percentage in Kupres, Privor and Stolac pramenka breeds 


\section{Conclusions}

The prediction of the milk yield and milk composition using the Guo-Swalve model could be utilised by the national breeding program for the Kupres, Privor and Stolac pramenka sheep breeds. However, this model should be used with caution in Privor and Stolac pramenka breed due to the high variation in milk yield throughout lactation. A standardised keeping practice, especially regarding the lambs management, would contribute towards the more succesfull milk production and recording. Kupres pramenka is the most distinct dairy ewe breed with favourable milk content using the high mountain pastures. Privor and Stolac pramenka breeds show a good dairy potential even when reared extensively using the highlands and submediterranean pastures.

\section{Modeli laktacijskih krivulja u bosanskohercegovačkih ovaca na ispaši}

\section{Sažetak}

Mlijeko kupreške, privorske i stolačke pramenke koristi se za proizvodnju kvalitetnih sireva. Zbog nedostatka znanja o količini i sastavu mlijeka ovih autohtonih bosanskohercegovačkih pasmina ovaca cilj je bio odrediti najbolji model koji opisuje njihove laktacije. Uzorci za količinu i sastav mlijeka (mliječna mast i protein) prikupljeni su u ranoj, srednjoj i kasnoj laktaciji te je bilježena količina mlijeka za 129 kupreških, 141 privorskih i 129 stolačkih pramenki. Uspoređena su četiri modela laktacijskih krivulja (Wilmink, kubni, Ali-Shaeffer i Guo-Swalve) i najprimjenjiviji model je biran temeljem najvećeg koeficijenta determinacije i najmanjeg korijena srednje kvadratne pogreške. Guo-Swalve model je najuspješnije opisao sve varijable. Kupreška pramenka pokazala se kao pasmina s najvećom proizvodnjom od 139 kg mlijeka u 175 dana laktacije (0,79 kg/d; između 50-og i 225-og dana laktacije) i standardnom laktacijskom krivuljom. Privorska pramenka je proizvela 118 kg mlijeka u 175 dana laktacije (0,67 kg/d), a Stolačka pramenka 101 kg mlijeka u 175 dana laktacije (0,58 kg/d). Laktaciju stolačke i privorske pasmine karakterizira atipična laktacijska krivulja koja je u stalnom padu i karakteristična je za ovce koje nisu selekcionirane za proizvodnju mlijeka. Predviđanje količine i sastava mlijeka GuoSwalve modelom moglo bi se koristiti u uzgojnom programu za kuprešku, privorsku i stolačku pramenku. Navedeni modeli se trebaju koristiti za privorsku i stolačku pramenku s oprezom jer njihova proizvodnja mlijeka tijekom laktacije je vrlo varijabilna.

Key words: ovčje mlijeko, sastav mlijeka, laktacijska krivulja, autohtone pasmine ovaca 
1. Ali, T.E., Schaeffer, L.R. (1987): Accounting for covariances among test day milk yields in dairy cows. Canadian Journal of Animal Science 67, 637-644. https://doi.org/10.4141/cjas87-067

2. Batinic, V., Salamon, D., Dzidic, A. (2011): Proizvodnja i kemijski sastav mlijeka autohtonih pasmina ovaca u Bosni i Hercegovini. Zbornik sažetaka 46. hrvatskog i 6. međunarodnog simpozija agronoma / Pospišil, Milan (Eds.). Zagreb: Agronomski fakultet. 225-226.

3. Batinic, V., Salamon, D., Ivankovic, S., Antunac, N., Dzidic, A. (2018a): Udder morphology, milk production, and composition in pasture-based dairy ewes during lactation. Abstracts of the 2018 American Dairy Science Association Annual Meeting/ Lucy, Matthew C. (Eds.). Champaign, IL 61820: American Dairy Science Association. 212-212.

4. Batinic, V., Salamon, D., Ivankovic, S., Antunac, N., Dzidic, A. (2018b): Comparison of lactation models in pasturebased dairy ewes in Bosnia and Herzegovina. Book of Abstracts of the $69^{\text {th }}$ Annual Meeting of the European Federation of Animal Science / EAAP (Eds.). Wageningen, The Netherlands: Wageningen Academic Publishers, 517-517.

5. Bilgin, O.C., Esenbuga, N., Davis, M.E. (2010): Comparison of models for describing the lactation curve of Awassi, Morkaraman and Tushin sheep. Archiv Tierzucht 53, 447456.

https://doi.org/10.5194/aab-53-447-2010

6. Cadavez, V.A., Silva, A., Malovrh, S., Kovac, M. (2008): Modelling lactation curves in dairy sheep rose under extensive production system. Proceeding of the $43^{\text {rd }}$ Croatian and $3^{\text {rd }}$ International Symposium on Agriculture Opatija, 845-848.

7. Cappio-Borlino, A., Portolano, B., Todaro, M., Macciotta, N.P.P., Giaccone, P., Pulina, G. (1997): Lactation curves of Valle del Belice dairy ewes for yields of milk, fat, and protein estimated with test day models. Journal of Dairy Science 80, 3023-3029. https://doi.org/10.3168/jds.s0022-0302(97)76269-6

8. Carta, A., Sanna, S.R., Casu, S. (1995): Estimating lactation curves and seasonal effects for milk, fat and protein in Sarda dairy sheep with a test day model. Livestock Production Science 44, 37-44. https://doi.org/10.1016/0301-6226(95)00051-1

9. Dozet, N., Stanisic, M., Parijez, S., Sumenic, S. (1974): Tendencije u proizvodnji autohtonih mliječnih proizvoda u Bosni i Hercegovini. Mljekarstvo 24 (8), 176-187.

10. Draganescu C., Grosu H. (2010): Valachian (Zackel) heritage philetic sheep group - a taxonomic problem. DAGENE. Retrieved May 24, 2012, from http:// ebookbrowse.com/draganescu-and-grosu-dagene-2010pdf-d58690637

11. Dzidic, A., Kaps, M., Bruckmaier, R. (2004): Machine milking of Istrian dairy crossbreed ewes: udder morphology and milking characteristics. Small Ruminant Research 55 (1-3), 183-189.

https://doi.org/10.1016/j.smallrumres.2004.02.003
12. Dzidic, A., Salamon, D., Kaic, A., Salajpal, K., Kaps, M. (2009): Relationship between udder and milking traits during lactation in Istrain dairy crossbreed ewes. Italian journal of animal science 8 (S3), 154-156. https://doi.org/10.4081/ijas.2009.s3.154

13. El-Saied, U.M, Carriedo, J.A., San Primitivo, F. (1998): Heritability of test day somatic cell counts and its relationship with milk yield and protein percentage in dairy ewes, Journal of Dairy Science 81, 2956-2961. https://doi.org/10.3168/jds.s0022-0302(98)75858-8

14. Elvira, L., Hernandez, F., Cuesta, P., Cano, S., GonzalezMartin, J., Astiz, S. (2013): Factors affecting the lactation curves of intensively managed sheep based on a clustering approach. Journal of Dairy Research, 80(4), 439-447. https://doi.org/10.1017/s0022029913000381

15. Gonzalo, C., Carriedo, J.A., San Primitivo, F. (1994): Factors influencing variation of test day milk yield, somatic cell count, fat, and protein in dairy sheep, Journal of Dairy Science 77, 1537-1542. https://doi.org/10.3168/jds.s0022-0302(94)77094-6

16. Guo, Z., Swalve, H.H. (1995): Modelling of the lactation curve as a sub-model in the evaluation of test day records. Proceedings of the INTERBULL Meeting, INTERBULL Bulletin No. 11, Department of Animal Breeding and Genetics, SLU, Uppsala, Sweden, p. 4.

17. IDF 128-2 (2009): Milk - Definition and evaluation of the overall accuracy of alternative methods of milk analysis - Part 2: Calibration and quality control in the dairy laboratory. International Dairy Federation, Brussels, Belgium. https://doi.org/10.3403/30162542u

18. Kaps, M., Spehar, M. (2004): Estimation of genetic parameters and breeding values of milk traits for Simmental cattle in Croatia using a lactation animal model. Agriculturae Conspectus Scientificus 69 (4), 91-94.

19. Karangeli, M., Abas, Z., Koutroumanidis, T., Malesios, C., Giannakopoulos, C. (2011): Comparison of Models for Describing the Lactation Curves of Chios Sheep Using Daily Records Obtained from an Automatic Milking System. Salampasis, M. and Matopoulos A. (Eds.) Proceedings of the $5^{\text {th }}$ International Conference on Information and Communication Technologies for Sustainable Agri-production and Environment HAICTA: 571-589.

20. Keskin, I., Dag, B. (2006): Comparison of different mathematical models for describing the complete lactation of Akkaraman ewes in Turkey. Asian-Australian Journal of Animal Science 19 (11), 1551-1555. https://doi.org/10.5713/ajas.2006.1551

21. Komprej, A., Gorjanc, G., Kompan, D., Kovač M. (2012): Lactation curves for milk yield, fat, and protein content in Slovenian dairy sheep. Czech Journal of Animal Science 57 (5), 231-239. https://doi.org/10.17221/5921-cjas 
22. Macciotta, N.P.P., Vicario, D., Cappio-Borlino, A. (2005): Detection of different shapes of lactation curve for milk yield in dairy cattle by empirical mathematical model. Journal of Dairy Science 88:1178-1191. https://doi.org/10.3168/jds.s0022-0302(05)72784-3

23. Oravcova, M., Margetin, M. (2015): First estimates of lactation curves in white shorthaired goats in Slovakia. Slovak Journal of Animal Science 48 (1), 1-7.

24. Oravcova, M., Margetin, M., Tancin, V. (2015): Daily milk yield, and milk fat and protein content. Mljekarstvo 65 (1), 48-56.

https://doi.org/10.15567/mljekarstvo.2015.0107

25. Pollott, G.E. (2000): A biological approach to lactation curve analysis for milk yield. Journal of Dairy Science 83: 2448-2458.

https://doi.org/10.3168/jds.s0022-0302(00)75136-8

26. Pollott, G.E., Gootwine, E. (2000): Appropriate mathematical models for describing the complete lactation of dairy sheep. Animal Science 71, 197-207. https://doi.org/10.1017/s1357729800055028

27. Pulina, G., Macciotta, N.P., Nudda, A. (2005): Milk composition and feeding in Italian dairy sheep. Italian Journal of Animal Science 1 (4), 5-14. https://doi.org/10.4081/ijas.2005.1s.5

28. Salamon, D., Dzidic, A. (2014): Preferences of Istrian sheep udder shape type on farms that apply machine milking. Acta agraria Kaposvariensis 18 (Supplement 1), 166-172.

29. Salamon, D., Furdic, P., Tesija, T., Dzidic, A. (2019): Genetic parameters for the external udder morphology in commercial farms of Istrian sheep from Croatia. Journal of central European agriculture 20 (1), 68-73. https://doi.org/10.5513/jcea01/20.1.2462
30. Salamon, D., Gutierrez-Gil, B., Arranz, J.J., Barreta, J., Batinić, V., Dzidic, A. (2014): Genetic diversity and differentiation of 12 eastern Adriatic and western Dinaric native sheep breeds using microsatellites. Animal 8 (2), 200-207. https://doi.org/10.1017/s1751731113002243

31. Turner, C.W. (1926): A quantitative form of expressing persistency of milk or fat secretion. Journal of Dairy Science 9 (2), 203-214. https://doi.org/10.3168/jds.s0022-0302(26)93888-5

32. Valverde, R.R., García-Muíz, J.G., Domínguez, R.N., Flores, A.R., Alvarado, M.R.M. (2004): Comparison of equations to estimate lactation curves using different sampling strategies in Angus and Brown Swiss cattle and their crosses. Veterinária México 35, 187-201.

33. Vázquez-Peláez, C.G., García-Muñiz, J.G., Lopez-Villalobos, N. (2014): Empirical models used for lactation curve analysis in the Chiapas sheep breed using random regression models. International Journal of Livestock Production 5 (3), 55-64. https://doi.org/10.5897/ijlp2013.0177

34. Wilmink, J.B.M. (1987): Adjustment of test-day milk, fat and protein yield for age, season and stage of lactation. Livestock Production Science 16, 335-348. https://doi.org/10.1016/0301-6226(87)90003-0 